\title{
1-Acetylvinyl Acrylates: New Captodative Olefins Bearing an Internal Probe for the Evaluation of the Relative Reactivity of Captodative against Electron-Deficient Double Bonds in Diels-Alder and Friedel-Crafts Reactions
}

\author{
Rafael Herrera ${ }^{a, b}$, Hugo A. Jiménez-Vázquez ${ }^{*, a}$, Francisco Delgado ${ }^{a}$, Björn C. G. Söderberg ${ }^{c}$ and \\ Joaquín Tamariz, ${ }^{*, a}$ \\ ${ }^{a}$ Departamento de Química Orgánica, Escuela Nacional de Ciencias Biológicas, Instituto Politécnico Nacional, \\ Prol. Carpio y Plan de Ayala, 11340 México, D.F., Mexico \\ ${ }^{b}$ Instituto de Investigaciones Quimicobiológicas, Universidad Michoacana de San Nicolás de Hidalgo, \\ Edif. B-1, Ciudad Universitaria, Francisco J. Mujica S/N, 58066 Morelia, Mich., Mexico \\ ${ }^{c}$ C. Eugene Bennett Department of Chemistry, West Virginia University, P.O. Box 6045, Morgantown, \\ West Virginia 26506-6045, USA
}

\begin{abstract}
As olefinas captodativas $\mathbf{3 a}$ e $\mathbf{3 b}$ derivadas dos ácidos metacrílico e trans-crotônico foram preparadas. A presença de uma segunda ligação dupla na molécula, atuando como marcador interno, permitiu-nos comparar sua reatividade relativa em reações de Diesl-Alder e Friedel-Crafts. A reatividade foi avaliada com ciclopentadieno (6) atuando como dieno em cicloadição Diels-Alder, e com furano (9) e tiofeno (10) como substratos heteroaromáticos Friedel-Crafts. Em ambos os processos, a ligação dupla da enona captodativa mostrou-se mais reativa que a do sistema acrílico. A teoria FMO considera essa quimiosseletividade como consequência da maior contribuição da enona ao orbital LUMO dessas moléculas. A pequena seletividade exo observada na cicloadição com $\mathbf{6}$ concorda com a maior estabilidade do estado de transição, de acordo com os resultados de cálculos B3LYP/6$311 \mathrm{G}(\mathrm{d}, \mathrm{p})$.
\end{abstract}

The captodative olefins 1-acetylvinyl esters of methacrylic and trans-crotonic acids, $\mathbf{3 a}$ and $\mathbf{3 b}$, have been prepared. The presence of a second double bond in the molecule, acting as an internal probe, allowed us to compare their relative reactivity in Diels-Alder and Friedel-Crafts reactions. The reactivity was evaluated with cyclopentadiene (6) as diene in Diels-Alder cycloadditions, and with furan $(\mathbf{9})$ and thiophene $(\mathbf{1 0})$ as heteroaromatic Friedel-Crafts substrates. In both processes, the captodative enone double bond proved to be more reactive than that in the acrylic moiety. FMO theory accounted for this chemoselectivity as a consequence of the major $\pi$ contribution of the enone to the LUMO of these molecules. The slight exo stereoselectivity observed in the cycloaddition to 6 parallels the higher stability of the corresponding transition state, according to the results of B3LYP/ 6-311G(d,p) calculations.

Keywords: captodative olefins, Friedel-Crafts, Diels-Alder cycloaddition, transition state calculations

\section{Introduction}

The captodative olefins 1-acetylvinyl arenecarboxylates, 1a-1c, have proved to be as reactive in DielsAlder additions as olefins substituted only with an electron-withdrawing group, such as methyl vinyl ketone (2). ${ }^{1}$ They have also shown high regio- and stereoselectivities with unsymmetrically substituted dienes in

\footnotetext{
* e-mail: jtamariz@woodward.encb.ipn.mx
}

these reactions. ${ }^{2}$ Moreover, in 1,3-dipolar cycloadditions with diverse nitrones, olefin $\mathbf{1 a}$ reacted faster than dipolarophile $\mathbf{2}$, with much higher regio- and stereoselectivities. ${ }^{3}$ However, from a perturbational point of view, ${ }^{4}$ captodative olefins should be less reactive and selective than alkenes substituted only with electronwithdrawing groups. Structural and theoretical studies of olefin 1a revealed that the delocalization of the oxygen lone pair of the electron-donor group toward the $\pi$-system was inhibited by conformational restrictions, ${ }^{5}$ also 
suggesting a dominant effect of the acetyl electronwithdrawing group on the polarization of the double bond. Moreover, the regioselectivity shown in 1,3-dipolar additions toward nitrones and nitrile oxides was rationalized by the DFT/HSAB theory, ${ }^{3}$ which showed the relevance of the electron-donor group in controlling the interaction of the cycloaddends. Therefore, it appears that electronic and structural factors might explain the reactivity and regiochemistry observed in both cycloaddition reactions.<smiles>[R]C(=O)C(=C)OC(=O)OBr</smiles><smiles>[R]C=C([R])C(=O)OC(=C)C(C)=O</smiles>

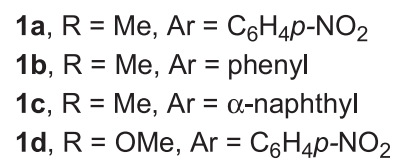

3a, $R^{1}=M e, R^{2}=H$ $3 b, R^{1}=H, R^{2}=M e$

In order to carry out a more profound evaluation of the effects involved in the control of the reactivity of captodative olefins, it would be interesting to design new captodative alkenes bearing a second activated double bond as an internal probe. It is likely that both double bond moieties would be subjected to similar solvent and reagent interactions, bearing out the relevant structural and electronic effects on the $\pi$ orbital that control reactivity. Accordingly, we hereby describe the preparation of the novel olefins $\mathbf{3 a}$ and $\mathbf{3 b}$, and their study as dienophiles in Diels-Alder additions, and as electrophiles in aromatic electrophilic substitution (AES), under FriedelCrafts conditions. Hartree-Fock $(\mathrm{HF} / 6-31 \mathrm{G}(\mathrm{d}, \mathrm{p}))$ and DFT (B3LYP/6-311G(d,p)) calculations were carried out to determine the most stable conformers of $\mathbf{3} \mathbf{a}$ and $\mathbf{3} \mathbf{b}$, and to evaluate the relative energies of the unoccupied MOs expected to be involved in the reactivity of these processes. In addition, in order to obtain a better understanding of the exo stereoselectivity commonly observed in the cycloaddition reactions of captodative olefins, we have determined (B3LYP/6-311G(d,p)) some of the possible

transition states in the Diels-Alder reaction of $\mathbf{3 a}$ and $\mathbf{3 b}$ with cyclopentadiene (6).

\section{Results}

Preparation of the captodative olefins 1-acetylvinyl acrylates $\mathbf{3 a}$ and $\mathbf{3 b}$

The method used previously ${ }^{1}$ for the preparation of compounds 1 was applied to the synthesis of captodative olefins $\mathbf{3 a}$ and $\mathbf{3 b}$, providing the expected products, although in very low yields $(<10 \%)$. The reaction conditions were improved by addition of the acryloyl chloride, $\mathbf{5} \mathbf{a}$ or $\mathbf{5 b}$, to the solution of butane-2,3-dione (4) at $-50{ }^{\circ} \mathrm{C}$, and maintaining the reaction at room temperature for $24 \mathrm{~h}$ (Scheme 1). Although the NMR spectra of the reaction crude showed only traces of byproducts, the yields of the purified compounds were low (3a, 26\%; 3b, 33\%). This was probably due to their instability to the purification process. Although different column chromatography supports (alumina, silica gel, florisil), and radial chromatography were tried, the best way to purify these compounds was by flash column chromatography through silica gel. Olefin 3c was also obtained, as shown by ${ }^{1} \mathrm{H}$ NMR of the corresponding reaction mixture, but it was not stable to purification conditions. Olefins $\mathbf{3 a}$ and $\mathbf{3 b}$ were fully characterized by spectroscopy and HRMS.

We have recently reported experimental and theoretical studies that confirm a planar conformation for the conjugated enone moiety of olefin 1a, which can adopt the two possible $s$-cis and $s$-trans conformations. ${ }^{5}$ Although the latter was found to be more stable, in both cases the conjugated aroyloxy group adopts an orthogonal conformation with respect to the plane of the enone. ${ }^{5}$ Our $a b$ initio calculations (B3LYP/6-311G(d,p)) of the four possible $s$-cis/s-trans conformers of olefin 3a show that the most stable geometry corresponds to that in which the enone fragment $(a)$ adopts the $s$-cis conformation, while the methacrylate moiety $(b)$ has the $s$-trans geometry. On the other hand, in the most stable conformer of olefin $\mathbf{3 b}$, the preferred conformation is the $s$-cis for both conjugated fragments (Figure 1). For both olefins, $\mathbf{3 a}$ and $\mathbf{3 b}$, the<smiles>CC(=O)C(C)=O</smiles><smiles>[R]C=C([R])C(=O)Cl</smiles>

4
5a, $\mathrm{R}^{1}=\mathrm{Me}, \mathrm{R}^{2}=\mathrm{H}$
5b, $R^{1}=H, R^{2}=M e$
5c, $R^{1}=R^{2}=H$

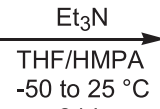

$24 \mathrm{~h}$<smiles>[R]C=C([R])C(=O)OC(=C)C(C)=O</smiles>

3a, $R^{1}=M e, R^{2}=H(26 \%)$

3b, $R^{1}=H, R^{2}=\operatorname{Me}(33 \%)$

3c, $R^{1}=R^{2}=H$

Scheme 1 . 
conjugated moieties $(a)$ and $(b)$ were, nevertheless, perpendicular to each other, paralleling the preferred conformations found for $\mathbf{1 a}$ and other captodative olefins. ${ }^{6}$ The four possible $s$-cis/s-trans conformers of both alkenes had similar energies, spanning a small energy range $(0.42$ $\mathrm{kcal} \mathrm{mol}^{-1}$ for $\mathbf{3 a}$, and $1.16 \mathrm{kcal} \mathrm{mol}^{-1}$ for $\mathbf{3 b}$; Table 1). Although these energy differences are not large enough to claim that one of the conformers is totally favored in the gas phase, it has been established that, for analogous small energy differences, the solid-state conformation of the conjugated acrylate system of alkene 1d, shows good agreement with the calculated gas phase structure. ${ }^{6}$

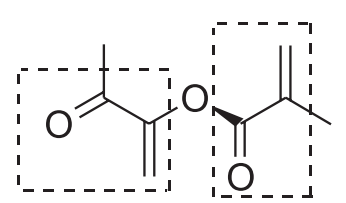

(a)

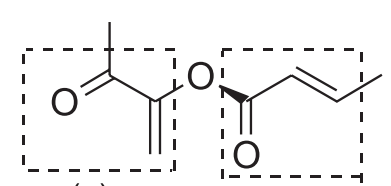

(a) (b) 3a, s-cis (a)/s-trans $(b)$

3b, s-cis $(a) / s-c i s(b)$

Figure 1. Structures of captodative olefins $\mathbf{3 a}$ and $\mathbf{3 b}$.

Table 1. Relative energies ${ }^{a}$ (B3LYP/6-311G(d,p)), in $\mathrm{kcal} \mathrm{mol}^{-1}$, of the four possible $s$-cis/s-trans conformers of $\mathbf{3 a}$ and $\mathbf{3} \mathbf{b}$

\begin{tabular}{lcccc}
\hline conformer $^{b}$ & \multicolumn{2}{c}{ 3a } & \multicolumn{2}{c}{ 3b } \\
& $\Delta E$ & $\Delta E_{0}$ & $\Delta E$ & $\Delta E_{0}$ \\
\hline s-cis/s-cis & 0.38 & 0.42 & 0.00 & 0.00 \\
s-cis $/$ s-trans & 0.00 & 0.00 & 0.83 & 0.86 \\
s-trans/s-cis & 0.37 & 0.42 & 0.46 & 0.45 \\
s-trans/s-trans & 0.21 & 0.18 & 1.19 & 1.16
\end{tabular}

${ }^{a} \Delta E$, relative electronic energies; $\Delta E_{0}$, relative energies including the zero-point correction. ${ }^{b}$ Refers to the enone/acrylate $s$-cis or $s$ trans conformation.

\section{Diels-Alder and Friedel-Crafts reactions of olefins $3 \boldsymbol{a}$ and} $3 b$

The reactivity and selectivity of these olefins in DielsAlder reactions were evaluated under thermal and catalytic conditions, using cyclopentadiene (6) as the diene (Table 2). Both exo and endo stereoisomers, 7 and $\mathbf{8}$, were obtained under mild thermal conditions (Scheme 2), showing a small preference for the exo isomers $7 \mathbf{a}$ and $\mathbf{7 b}$ (Table 2, entries 1 and 11). The structure of the major stereoisomers was established by NMR spectroscopy, and by comparison with spectroscopic data of the unambiguously established structures of adducts of olefin $1 \mathbf{1 a}^{7}$ The exo stereoselectivity was slightly improved by adding Lewis acid catalysts, although it depended on the type and amount of the catalyst used. For instance, for dienophile 3a, the best results were obtained with 1.0 mol equiv. of aluminum chloride or titanium chloride (Table 2, entries 2 and 7); while for $\mathbf{3 b}$, only the former catalyst and $\mathrm{ZnI}_{2}$ were able to slightly enhance the exo selectivity with respect to the thermal trial (Table 2, entries 12 and 14). The exo selectivity obtained for dienophiles $\mathbf{3} \mathbf{a}$ and $\mathbf{3 b}$ was similar to that shown by captodative olefins $\mathbf{1 a - 1 c},{ }^{1}$ and by other captodative olefins. ${ }^{8}$

It is worth noticing that, in all cases, the addition took place only at the enone double bond, even in the catalyzed trials. This chemoselectivity indicates a higher reactivity of this double bond in comparison with that of the acrylate moiety, under Diels-Alder conditions. This behavior is not unexpected, considering that the ester carbonyl group has a lesser electron-withdrawing effect than the ketone carbonyl group. ${ }^{6}$ This would support the hypothesis that the reactivity of this kind of captodative olefins is controlled mainly by the electronic effect of the electronwithdrawing group. ${ }^{5}$

Olefin 1a reacts with furan (9) under Lewis acid catalysis to give the Friedel-Crafts product, the aromatic electrophilic substitution taking place at the C-2 carbon of the heterocycle. ${ }^{9}$ A strong electron-withdrawing effect is required in the Michael acceptors for an efficient Friedel-Crafts reaction. ${ }^{10}$ Hence, this reaction could be a sensitive method to evaluate the reactivity of the potential Michael bis-acceptors 3a and 3b. Thus, under Lewis acid catalysis $\left(\mathrm{BF} \cdot \mathrm{Et}_{2} \mathrm{O}\right)$ at low temperature $\left(-78^{\circ} \mathrm{C}\right)$, alkene $3 \mathbf{a}$ reacted with 9 to give a single<smiles>[R]C=C([R])C(=O)OC(=C)C(C)=O</smiles>

3a, $R^{1}=M e, R^{2}=H$ 3b, $R^{1}=H, R^{2}=M e$

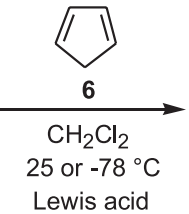

Lewis acid

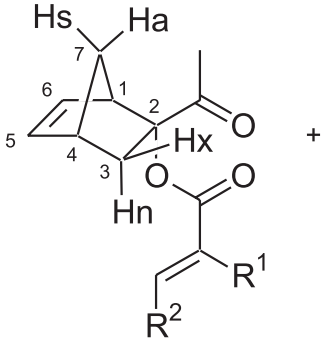

$$
\begin{aligned}
& 7 a, R^{1}=M e, R^{2}=H \\
& 7 b, R^{1}=H, R^{2}=M e
\end{aligned}
$$

Scheme 2. 
product (11a), arising from addition to the enone double bond (Scheme 3). Again, the acrylic double bond was reluctant to undergo the addition, even for acceptor $\mathbf{3 b}$, since the FriedelCrafts reaction with 9 provided the product of addition to the enone $\mathbf{1 1 b}$ (Scheme 3).

A similar behavior was found for both alkenes $\mathbf{3 a}$ and 3b when the electrophilic substitution was performed on thiophene (10). As in the case of 9, the incoming Michael acceptor was directed to the $\mathrm{C}$-2 position of the heterocycle (Scheme 3). The ${ }^{1} \mathrm{H}$ NMR analysis of reaction crudes did not show any product arising from the Friedel-Crafts reaction at the acryloxy double bond $(b)$. The moderate yields of the adducts were due to their low stability under the column chromatography carried out on silica gel.

\section{Discussion}

FMO theory has predicted correctly the difference in reactivity for Diels-Alder additions of captodative olefin 1a with respect to olefin 1d. ${ }^{2,5,6}$ Thus, for the energetically more favorable HOMO-diene/LUMO-dienophile gap, the LUMO energy for $\mathbf{1 a}$ was lower than that of $\mathbf{1 d}$, predicting a faster addition towards a diene such as $\mathbf{6}$ for the former alkene, which agrees with experimental results. Furthermore, the relative FMO energies of 1a fit well the experimental values of ionization energies (IE) and electron affinities (EA). ${ }^{5,6}$ Therefore, considering that in alkenes 1a and 1d the electron-donating group is the same, and the steric interactions are similar, one can consider that the double bond in the enone frame is more reactive than that of the acrylate moiety.

Consequently, for alkene $\mathbf{3 a}$, the enone system $(a)$ should be more reactive than the acrylate fragment $(b)$, regardless of the effect of the electron-donating group. This should be detected by comparison of the coefficient contributions of both moieties to the LUMO. We calculated the FMO energies and coefficients $(\mathrm{HF} / 6-31 \mathrm{G}(\mathrm{d}, \mathrm{p})$ ) for the most stable geometries of $\mathbf{3 a}$ and $\mathbf{3 b}$ (Table 3). The LUMO energies of both systems are quite similar, being that of $\mathbf{3 a}$ lower. The atomic wave function coefficients of the LUMOs are localized mainly at the double bond of the enone moiety, and not at the acrylate double bond. The main contribution of the latter fragment is found in the next unoccupied orbitals (LUMO+1) in both, $\mathbf{3 a}$ and $\mathbf{3 b}$ (Table 3).

If we consider that $\mathbf{3 a}$ is a bis-captodative olefin, from the point of view of the electron donor groups, the methyl

Table 2. Diels-Alder cycloadditions of olefins $\mathbf{3 a}$ and $\mathbf{3 b}$ with cyclopentadiene $(\mathbf{6})^{a}$

\begin{tabular}{|c|c|c|c|c|c|c|}
\hline Entry & Olefin & Catalyst (mol equiv.) & $\mathrm{T}\left({ }^{\circ} \mathrm{C}\right)$ & $\mathrm{t}(\mathrm{h})$ & Products $(\text { ratio })^{b}$ & $\operatorname{Yield}(\%)^{c}$ \\
\hline 1 & $3 \mathbf{a}$ & - & 25 & 3 & $\mathbf{7 a} / \mathbf{8 a}(69: 31)$ & 83 \\
\hline 2 & $3 \mathbf{a}$ & $\mathrm{AlCl}_{3}(1.0)$ & -78 & 3 & $\mathbf{7 a} / \mathbf{8 a}(74: 26)$ & 76 \\
\hline 3 & $3 \mathbf{a}$ & $\mathrm{AlCl}_{3}(2.0)$ & -78 & 3 & $\mathbf{7 a} / \mathbf{8 a}(72: 28)$ & 89 \\
\hline 4 & $3 \mathbf{a}$ & $\mathrm{AlCl}_{3}(3.0)$ & -78 & 3 & 7a/8a $(62: 38)$ & 90 \\
\hline 5 & $3 \mathbf{a}$ & $\mathrm{AlCl}_{3}(5.0)$ & -78 & 3 & $\mathbf{7 a} / \mathbf{8 a}(68: 32)$ & 84 \\
\hline 6 & $3 \mathbf{a}$ & $\mathrm{TiCl}_{4}(0.3)$ & -78 & 3 & $\mathbf{7 a / 8 a}(57: 43)$ & 56 \\
\hline 7 & $3 \mathbf{a}$ & $\mathrm{TiCl}_{4}(1.0)$ & -78 & 3 & $7 \mathbf{a} / 8 \mathbf{a}(75: 25)$ & 62 \\
\hline 8 & $3 \mathbf{a}$ & $\mathrm{ZnI}_{2}(1.0)$ & -78 & 10 & 7a/8a $(57: 43)$ & 52 \\
\hline 9 & $3 \mathbf{a}$ & $\mathrm{BF}_{3} \cdot \mathrm{Et}_{2} \mathrm{O}(0.5)$ & -78 & 3 & 7a/8a $(68: 32)$ & 43 \\
\hline 10 & $3 \mathbf{a}$ & $\mathrm{BF}_{3} \cdot \mathrm{Et}_{2} \mathrm{O}(1.0)$ & -78 & 3 & $\mathbf{7 a} / \mathbf{8 a}(63: 37)$ & 68 \\
\hline 11 & $3 \mathbf{b}$ & - & 25 & 3 & 7b/8b $(59: 41)$ & 78 \\
\hline 12 & $3 \mathbf{b}$ & $\mathrm{AlCl}_{3}(1.0)$ & -78 & 3 & 7b/8b (68:32) & 61 \\
\hline 13 & $3 \mathbf{b}$ & $\mathrm{TiCl}_{4}(1.0)$ & -78 & 3 & 7b/8b $(54: 46)$ & 48 \\
\hline 14 & 3b & $\mathrm{ZnI}_{2}(1.0)$ & -78 & 10 & $\mathbf{7 b} / \mathbf{8 b}(61: 39)$ & 64 \\
\hline
\end{tabular}

${ }^{a}$ All under $\mathrm{N}_{2}$ atmosphere, using $\mathrm{CH}_{2} \mathrm{Cl}_{2}$ as solvent, with 1.3 mol equiv. of diene 6. Thermal trials in the presence of $1-2 \%$ hydroquinone;

${ }^{b}$ Proportions as determined by ${ }^{1} \mathrm{H}$ NMR of the crude reaction mixtures; ${ }^{c}$ As a mixture of isomers after purification by column chromatography.

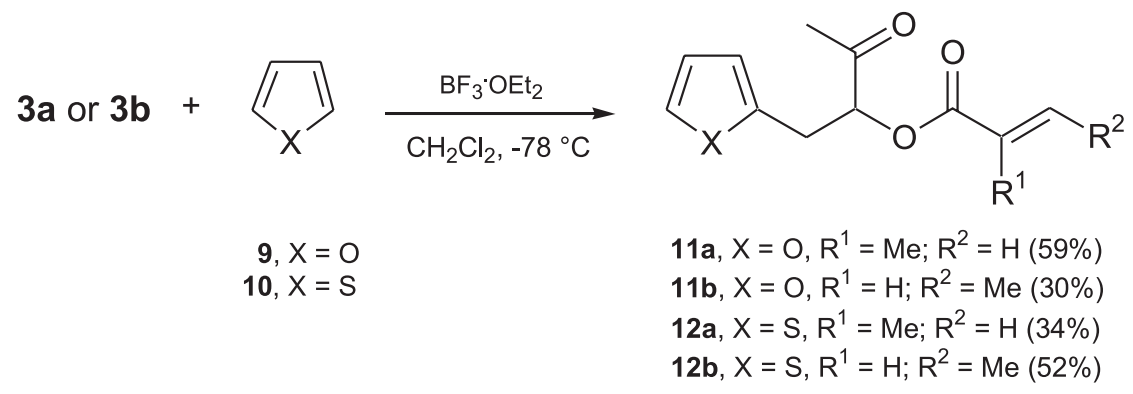

Scheme 3. 
group of the acrylate moiety of this compound would be less electron-donating (by hyperconjugation of the $\mathrm{C}-\mathrm{H}$ bonds) than the oxygen atom (by conjugation of the electron-lone pairs) on the other captodative double bond. Hence, one could expect a higher reactivity of the acrylic double bond with reagents such as cyclopentadiene (6) in Diels-Alder additions, and with heterocycles in FriedelCrafts reactions. In contrast to this expectation, the additions to the methacrylic double bond were not observed. This might be ascribed to the following effects: (i) the inhibition of conjugation of the lone pairs of the oxygen atom in the captodative enone moiety due to the conformational preference, which impedes an efficient overlapping between these electrons and the $\pi$ orbital of the double bond; ${ }^{5}$ and (ii) the inductive electronwithdrawing effect of the enol ester. ${ }^{1}$

It is interesting to notice that the largest coefficient in the unoccupied MOs, involving the double bonds of the enone and acrylate fragments, is found at the beta terminal carbon for both alkenes $\mathbf{3 a}$ and $\mathbf{3} \mathbf{b}$, as observed for the captodative double bond of alkenes $\mathbf{1}$.

The major atomic coefficient contributions of the enone double bond $(a)$ to the LUMO of olefins $\mathbf{3} \mathbf{a}$ and $\mathbf{3 b}$, indicate that this double bond should be the one mostly involved in the Diels-Alder reaction, as experimentally observed. A similar suggestion could also be made for the chemoselectivity associated to observed in the Friedel-Crafts reaction, since the $\pi$ electron density of the benzene ring, playing the role of the nucleophile (interacting through the HOMO), would react with the best Michael acceptor as the electrophile (interacting through the LUMO). ${ }^{11}$
No obvious reason can account for the slight exo stereoselectivity displayed in the cycloaddition of olefins 3 to cyclopentadiene (6), nor for the lack of significant changes on this selectivity by modifying the reaction conditions from thermal to catalytic, due to the large number of possible stabilizing and destabilizing interactions between diene and dienophile at the transition state. ${ }^{6,12}$ Therefore, we have undertaken the calculation of the transition states (TS) using the hybrid DFT method B3LYP/6-311G(d,p) for the cycloaddition of diene 6 to the enone double bond of alkenes $\mathbf{3 a}$ and $\mathbf{3 b}$. Taking into consideration the small energy differences among the conformers of both alkenes (Table 1), and the fact that not necessarily the most stable conformers of the reactants lead to the most stable transition states, we determined eight possible transition states for each alkene. We considered only the endo and exo approaches of $\mathbf{6}$ to the face of the enone double bond opposite to the carbonyl of the ester, on the grounds that this face would be the one with the least steric interactions (Figure 2). The determination of these endo and exo transition states was carried out for each one of the four conformers of $\mathbf{3 a}$ and $\mathbf{3 b}$. At the same time, we obtained the geometries and energies of the products derived from each one of the transition states. The results are summarized in Tables 4 and 5 .

It is worth noticing that for both alkenes the most stable transition states (Tables 4 and 5) are those arising from the exo approach of $\mathbf{6}$ to the lowest-energy conformer of the captodative olefin (Figure 2), in agreement with the experimental results. In addition, the lowest-energy endo transition states also correspond to the approach of the

Table 3. Ab initio $(\mathrm{HF} / 6-31 \mathrm{G}(\mathrm{d}, \mathrm{p}))$ energies $(\mathrm{eV})$ and atomic coefficientes $(\mathrm{Ci})$ of the frontier molecular orbitals for olefins $\mathbf{3 a}$ and $\mathbf{3 b}{ }^{a}$

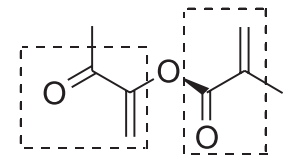

(a) (b)

3a, s-cis $(a) / s-t r a n s(b)$

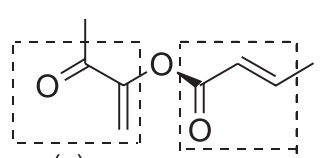

(a)

(b)

3b, s-cis $(a) / s-c i s(b)$

\begin{tabular}{|c|c|c|c|c|c|c|c|c|c|c|}
\hline \multirow[b]{2}{*}{ Compd. ${ }^{d}$} & \multicolumn{5}{|c|}{$\mathrm{HOMO}^{b}$} & \multicolumn{5}{|c|}{$\mathrm{LUMO}^{c}$} \\
\hline & $\mathrm{E}(\mathrm{eV})$ & $C 1$ & $C 2$ & $C 3$ & $C 4$ & $E(e V)$ & $C 1$ & $C 2$ & $C 3$ & $C 4$ \\
\hline 3a $(a)$ & -10.436 & 0.3044 & 0.3129 & -0.0284 & -0.1717 & 2.761 & 0.2405 & -0.1880 & -0.2305 & 0.2077 \\
\hline $\mathbf{3 a}(b)$ & -10.606 & 0.2982 & 0.3011 & -0.0072 & -0.1239 & 2.945 & 0.2554 & -0.1967 & -0.2279 & 0.1815 \\
\hline 3b $(a)$ & -10.357 & 0.3325 & 0.3423 & -0.0306 & -0.1880 & 2.813 & 0.2206 & -0.1717 & -0.2080 & 0.1873 \\
\hline $\mathbf{3 b}(b)$ & -10.560 & 0.2950 & 0.3543 & -0.0050 & -0.1858 & 3.044 & 0.2579 & -0.1607 & -0.2011 & 0.1425 \\
\hline
\end{tabular}

${ }^{a}$ These are the values of the $p z$ coefficients, the relative $p z$ ' contributions are analogous; ${ }^{b}$ Energy of the HOMOs of olefins $\mathbf{3 a}$ and $\mathbf{3 b}$, with the coefficient contributions located at the enone moiety $(a)$. The energy and coefficients of the acrylate moiety $(b)$ correspond to those found at the HOMO-1 orbitals; ${ }^{c}$ Energies of the LUMOs of olefins $\mathbf{3 a}$ and $\mathbf{3 b}$, with coefficient contributions located at the enone $(a)$ moiety. The energies and coefficients of olefins $\mathbf{3 a}$ and $\mathbf{3} \mathbf{b}$ for the acrylate moiety $(b)$ correspond to those found at the LUMO+1 orbitals; ${ }^{d}$ For the most stable nonplanar s-cis/s-trans conformation of the $(a)$ and $(b)$ moieties of olefin 3a, and the $s$-cis/s-cis conformation of the $(a)$ and $(b)$ moieties of olefin 3b (Table 1). 


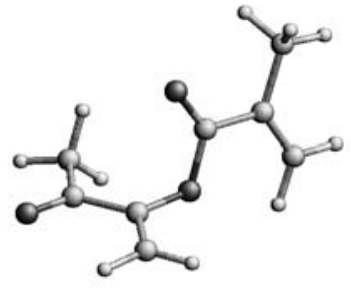

3a cis/trans

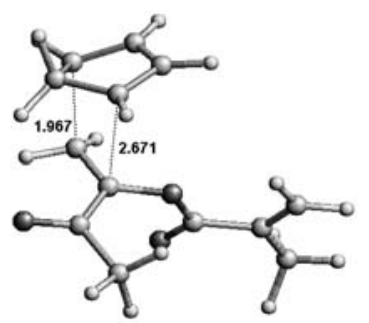

3a exo-cis/trans $\mathbf{T S}$

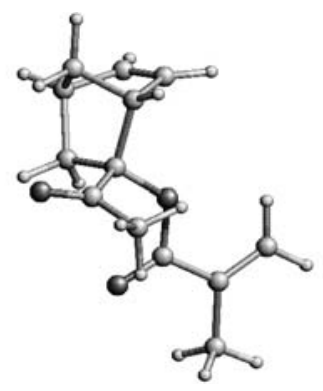

7a exo-cis/trans

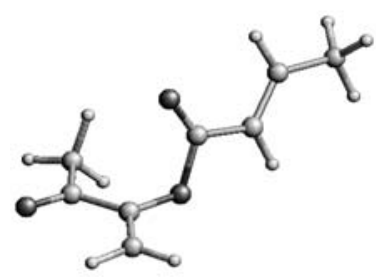

3b $c i s / c i s$
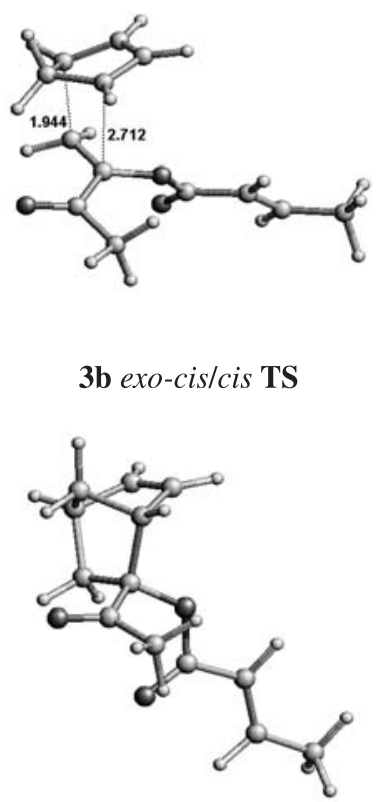

$7 \mathbf{b}$ exo-cis/cis 3b exo-cis/cis $\mathbf{T S}$

Figure 2. B3LYP/6-311G(d,p) geometries for: The lowest-energy conformers of $\mathbf{3 a}$ and $\mathbf{3 b}$ (above); the most stable transition states for the cycloaddition of $\mathbf{6}$ to $\mathbf{3 a}$ and $\mathbf{3 b}$ (middle); the most stable adducts of the cycloaddition of $\mathbf{6}$ to $\mathbf{3 a}$ and $\mathbf{3 b}$ (below). diene to the most stable conformers of the $\mathbf{3} \mathbf{a}$ and $\mathbf{3 b}$. The quasi-orthogonal conformation of the acrylate electrondonating group with respect to the enone $\pi$-plane is maintained at the transition state. The preference for the $s$ cis conformation of the enone at both endo and exo TSs has been attributed to its greater electrophilicity. ${ }^{13}$

Even though the energy differences shown in Tables 4 and $5\left(\Delta E\right.$ or $\left.\Delta E_{0}\right)$ are relatively small between the exo/ endo TSs, they reflect the small ratios of the corresponding adducts $\mathbf{7 / 8}$ for the thermal experimental trials (Table 3 , entries 1 and 11). However, there is no significant correspondence between these energy differences and the higher exo preference (exo/endo, 69:31) for dienophile 3a with respect to that found for dienophile $\mathbf{3 b}$ (exo/endo, 59:41), since the energy difference $\left(\Delta \Delta E_{0}\right)$ between the lowest-energy exo and endo transition states is $0.77 \mathrm{kcal}$ mol $^{-1}$ stereoselectivity for $\mathbf{3 a}$ and $0.89 \mathrm{kcal} \mathrm{mol}^{-1}$ for $\mathbf{3 b}$.

Analysis of the relative energies $\left(\Delta E\right.$ or $\left.\Delta E_{0}\right)$ of all possible adducts of $\mathbf{7}$ and $\mathbf{8}$ shows that the exo adducts $7 \mathbf{a}$ and $\mathbf{7 b}$ are quite more stable than the endo adducts $\mathbf{8 a}$ and $\mathbf{8 b}$, respectively (Tables 4 and 5). Therefore, for these cycloadditions, the major exo adducts 7 seem to be both the thermodynamic and kinetic products.

For both additions between diene $\mathbf{6}$ and olefins $\mathbf{3 a}$ and $3 \mathbf{b}$, of the two $\sigma$ bonds being formed in all endo and exo transition states, a much stronger interaction is found between carbon $\mathrm{C}-1$ of the diene and the terminal carbon $\mathrm{C}-1$ of the dienophile, since it presents a more developed $\sigma$ bond than the $\sigma$ bond between carbon C-4 of the diene and C-2 of the olefin (Figure 2), as suggested by the internuclear distances measured between these reaction centers (the internuclear distances shown in Figure 2 are very similar to those measured in all the other TSs).

Table 4. B3LYP/6-311G(d,p) electronic energies $(E \mathrm{e})$ and electronic + zero-point energies $(\mathrm{ZPE})\left(E_{0}\right)(\mathrm{au})$, and relative energies $(\Delta E)\left(\mathrm{kcal} \text { mol }{ }^{-1}\right)^{a}$ of the endo and exo TSs, and of the adducts $\mathbf{7}$ and $\mathbf{8}$, for the Diels-Alder cycloadditions of olefin 3a to cyclopentadiene (6)

\begin{tabular}{|c|c|c|c|c|c|c|}
\hline Entry & Olefin or Adduct & TS or Adduct ${ }^{b}$ & $E$ & $E_{0}$ & $\Delta E$ & $\Delta E_{0}$ \\
\hline 1 & $3 \mathbf{a}$ & endo/cis-cis & -730.782272 & -730.523327 & 1.30 & 1.25 \\
\hline 2 & $3 \mathbf{a}$ & exo/cis-cis & -730.783680 & -730.524614 & 0.42 & 0.44 \\
\hline 3 & $3 \mathbf{a}$ & endo/cis-trans & -730.783051 & -730.524090 & 0.82 & 0.77 \\
\hline 4 & $3 \mathbf{a}$ & exo/cis-trans & -730.784350 & -730.525321 & 0.00 & 0.00 \\
\hline 5 & $3 \mathbf{a}$ & endoltrans-cis & -730.777840 & -730.518495 & 4.08 & 4.28 \\
\hline 6 & $3 \mathbf{a}$ & exoltrans-cis & -730.775574 & -730.516478 & 5.51 & 5.55 \\
\hline 7 & $3 \mathbf{a}$ & endoltrans-trans & -730.778033 & -730.518757 & 3.96 & 4.12 \\
\hline 8 & $3 \mathbf{a}$ & exoltrans-trans & -730.775581 & -730.516644 & 5.50 & 5.44 \\
\hline 9 & $8 \mathbf{a}$ & endo/cis-cis & -730.835915 & -730.571922 & 1.25 & 1.11 \\
\hline 10 & $7 \mathbf{a}$ & exo/cis-cis & -730.837666 & -730.573311 & 0.15 & 0.24 \\
\hline 11 & $8 \mathbf{a}$ & endo/cis-trans & -730.836424 & -730.572487 & 0.93 & 0.76 \\
\hline 12 & $7 \mathbf{a}$ & exo/cis-trans & -730.837912 & -730.573697 & 0.00 & 0.00 \\
\hline 13 & $8 \mathbf{a}$ & endo/trans-cis & -730.833987 & -730.569788 & 2.46 & 2.45 \\
\hline 14 & $7 \mathbf{a}$ & exoltrans-cis & -730.832258 & -730.567938 & 3.55 & 3.61 \\
\hline 15 & $8 \mathbf{a}$ & endoltrans-trans & -730.834186 & -730.570069 & 2.34 & 2.28 \\
\hline 16 & $7 \mathbf{a}$ & exoltrans-trans & -730.832151 & -730.568049 & 3.61 & 3.54 \\
\hline
\end{tabular}

${ }^{a}$ Relative to the most stable TS or adduct. ${ }^{b}$ Stereochemistry of the TS or adduct/stereochemistry of the alkene conformer (as defined in Table 1 ). 
Table 5. B3LYP/6-311G(d,p) electronic energies $(E \mathrm{e})$ and electronic + zero-point energies (ZPE) $\left(E_{0}\right)(\mathrm{au})$, and relative energies $(\Delta E)^{a}(\mathrm{kcal}$ $\mathrm{mol}^{-1}$ ) of the endo and exo TSs, and of the adducts $\mathbf{7}$ and $\mathbf{8}$, for the Diels-Alder cycloadditions of olefin $\mathbf{3 b}$ to cyclopentadiene (6)

\begin{tabular}{|c|c|c|c|c|c|c|}
\hline Entry & Olefin or Adduct & TS or Adduct ${ }^{b}$ & E & $E_{0}$ & $\Delta E$ & $\Delta E_{0}$ \\
\hline 1 & $3 \mathbf{b}$ & endo/cis-cis & -730.786628 & -730.527557 & 0.92 & 0.89 \\
\hline 2 & $3 \mathbf{b}$ & exo/cis-cis & -730.788099 & -730.528969 & 0.00 & 0.00 \\
\hline 3 & $3 b$ & endo/cis-trans & -730.784911 & -730.525853 & 2.00 & 1.96 \\
\hline 4 & $3 b$ & exo/cis-trans & -730.786271 & -730.527065 & 1.15 & 1.19 \\
\hline 5 & $3 b$ & endo/trans-cis & -730.781317 & -730.521881 & 4.26 & 4.45 \\
\hline 6 & $3 b$ & exo/trans-cis & -730.778803 & -730.519572 & 5.83 & 5.90 \\
\hline 7 & $3 b$ & endoltrans-trans & -730.779817 & -730.520502 & 5.20 & 5.31 \\
\hline 8 & $3 b$ & exo/trans-trans & -730.777438 & -730.518270 & 6.69 & 6.71 \\
\hline 9 & $8 \mathbf{b}$ & endo/cis-cis & -730.840025 & -730.575907 & 0.96 & 0.84 \\
\hline 10 & $7 b$ & exo/cis-cis & -730.841555 & -730.577243 & 0.00 & 0.00 \\
\hline 11 & $8 b$ & endo/cis-trans & -730.838428 & -730.574338 & 1.96 & 1.82 \\
\hline 12 & $7 \mathrm{~b}$ & exo/cis-trans & -730.839957 & -730.575567 & 1.00 & 1.05 \\
\hline 13 & $8 b$ & endoltrans-cis & -730.837636 & -730.573445 & 2.46 & 2.38 \\
\hline 14 & $7 b$ & exoltrans-cis & -730.835674 & -730.571434 & 3.69 & 3.65 \\
\hline 15 & $8 b$ & endo/trans-trans & -730.836245 & -730.571874 & 3.33 & 3.37 \\
\hline 16 & $7 b$ & exoltrans-trans & -730.834340 & -730.569849 & 4.53 & 4.64 \\
\hline
\end{tabular}

${ }^{a}$ Relative to the most stable TS or adduct; ${ }^{b}$ Stereochemistry of the TS or adduct/stereochemistry of the alkene conformer (as defined in Table 1 ).

The slightly higher stability of the exo transition state may be the result of a delicate balance between steric and electronic interactions between the substituents of the dienophile, the methylene bridge, ${ }^{8,14}$ and the $\pi$ system of the diene. ${ }^{15}$

\section{Conclusions}

The new bis-captodative olefin 3a and captodative olefin $\mathbf{3 b}$ have been prepared from biacetyl (4) and the corresponding acryloyl chlorides $\mathbf{5 a}$ and $\mathbf{5 b}$. Highly chemoselective Diels-Alder cycloadditions and FriedelCrafts reactions were observed when olefins 3 reacted with cyclopentadiene (6) and heterocycles 9 and 10, respectively, showing exclusive addition to the enone moiety. FMO calculations, in agreement with these experimental results, indicate a significant $\pi$ contribution of the enone double bond to the LUMO, suggesting that the addition reactions should take place there, and not on the acrylic double bond of the captodative olefins $\mathbf{3}$.

The exo stereoselectivity shown by olefins 3 with diene 6 was accounted for by the lower energy calculated for the exo transition states, in comparison with the endo. Additional calculations at the ground state showed that the exo adducts 7 were also the thermodynamic products.

\section{Experimental}

\section{General}

Melting points (uncorrected) were determined with an electrothermal capillary melting point apparatus. IR spectra were recorded on a Perkin-Elmer 1600 spectrophotometer. ${ }^{1} \mathrm{H}(300 \mathrm{MHz})$ and ${ }^{13} \mathrm{C}(75.4 \mathrm{MHz}) \mathrm{NMR}$ spectra were recorded on a Varian Mercury instrument, in $\mathrm{CDCl}_{3}$ as solvent and TMS as internal standard. Mass spectra (MS) and high resolution mass spectrometry (HRMS) were obtained, in electron impact (EI) $(70 \mathrm{eV})$ and fast atom bombardment (FAB) modes, on a Hewlett-Packard 5971A, and on a Jeol JMS-AX 505 HA spectrometers. Microanalyses were performed by M-H-W Laboratories (Phoenix, AZ). Analytical thin-layer chromatography was performed using E. Merck silica gel 60 F254 coated 0.25 plates, visualizing by long- and short-wavelength UV lamps. Flash column chromatography was performed on silica gel (230-400 mesh, Natland Int.). Radial chromatography was performed on a Chromatotron of Harrison Research Instruments. All air moisture sensitive reactions were carried out under nitrogen using oven-dried glassware. THF was freshly distilled from sodium, and methylene chloride from calcium hydride, prior to use. Triethylamine was freshly distilled from $\mathrm{NaOH}$. All other reagents were used without further purification.

General procedure for the preparation of olefins $\mathbf{3 a}$ and $\mathbf{3 b}$

To a solution of $5.0 \mathrm{~mL}(0.036 \mathrm{~mol})$ of triethylamine in dry THF $(20 \mathrm{~mL})$ and HMPA $(1.0 \mathrm{~mL})$, at $-50{ }^{\circ} \mathrm{C}$ and under an $\mathrm{N}_{2}$ atmosphere, the acryloyl chloride $\mathbf{5}$ diluted in dry THF (10 mL) was slowly added. Then, at the same temperature, $2.41 \mathrm{~g}(0.028 \mathrm{~mol})$ of butane-2,3-dione (4) diluted in dry THF $(10 \mathrm{~mL})$ were added dropwise. After being stirred at room temperature for $24 \mathrm{~h}$, the solvent was removed under vacuum, the residue was dissolved in 
$\mathrm{CH}_{2} \mathrm{Cl}_{2}(50 \mathrm{~mL})$, and an aqueous saturated solution of $\mathrm{NH}_{4} \mathrm{Cl}(100 \mathrm{~mL})$ was added. The aqueous layer was extracted with $\mathrm{CH}_{2} \mathrm{Cl}_{2}(3 \times 50 \mathrm{~mL})$. The combined organic extracts were dried $\left(\mathrm{MgSO}_{4}\right)$, and the solvent was evaporated under vacuum. The residue was successively purified by flash column chromatography on silica gel (20 g, hexane/EtOAc, 95:5), and by radial chromatography (hexane/EtOAc, 95:5), to give the corresponding olefins $\mathbf{3 a}$ and $\mathbf{3 b}$.

\section{1-Acetylvinyl 2-methylacrylate (3a)}

Following the general procedure with $2.19 \mathrm{~g}(0.021$ mol) of 5a, afforded $0.84 \mathrm{~g}(26 \%)$ of $\mathbf{3 a}$ as a pale green oil. Rf 0.7 (hexane/EtOAc, 8:2). ${ }^{1} \mathrm{H} \mathrm{NMR}\left(300 \mathrm{MHz}, \mathrm{CDCl}_{3}\right) \delta$ $2.01\left(\mathrm{~s}, 3 \mathrm{H}, \mathrm{CH}_{3} \mathrm{C}=\right), 2.37\left(\mathrm{~s}, 3 \mathrm{H}, \mathrm{CH}_{3} \mathrm{CO}\right), 5.65(\mathrm{~d}, J 2.4 \mathrm{~Hz}$, 1H, H-4), 5.73-5.76 (m, 1H, H-7), 5.96 (d, J 2.4 Hz, 1H, $\mathrm{H}-4), 6.29$ (br s, $1 \mathrm{H}, \mathrm{H}-7) .{ }^{13} \mathrm{C} \mathrm{NMR}\left(75.4 \mathrm{MHz}, \mathrm{CDCl}_{3}\right.$ ) $\delta 18.2\left(\mathrm{CH}_{3} \mathrm{C}=\right), 25.5\left(\mathrm{CH}_{3} \mathrm{CO}\right), 113.8(\mathrm{C}-4), 127.9(\mathrm{C}-7)$, 134.9 (C-6), 151.7 (C-3), 165.3 (C-5), $191.7\left(\mathrm{COCH}_{3}\right)$. IR (film) $v_{\max } / \mathrm{cm}^{-1}: 1770,1737,1699,1639,1368,1290,1124$. HRMS (FAB, $\left.\mathrm{MH}^{+}\right)$( $\left.m \mathrm{NBA}\right)$ : Found 155.0700; Calc. for $\mathrm{C}_{8} \mathrm{H}_{11} \mathrm{O}_{3}: 155.0708$.

\section{But-2-enoic acid 1-acetylvinyl ester (3b)}

Following the general procedure with $2.19 \mathrm{~g}(0.021$ $\mathrm{mol})$ of $\mathbf{5 b}$, afforded $1.06 \mathrm{~g}(33 \%)$ of $\mathbf{3 b}$ as a pale green oil. Rf 0.57 (hexane/EtOAc, 8:2). ${ }^{1} \mathrm{H}$ NMR (300 $\mathrm{MHz}, \mathrm{CDCl}_{3}$ ) $\delta 1.94\left(\mathrm{dd}, J 6.9,1.7 \mathrm{~Hz}, 3 \mathrm{H}, \mathrm{CH}_{3} \mathrm{C}=\right), 2.36$ (s, 3H, $\mathrm{CH}_{3} \mathrm{CO}$ ), 5.62 (d, J $2.3 \mathrm{~Hz}, 1 \mathrm{H}, \mathrm{H}-4), 5.94$ (d, J $2.3 \mathrm{~Hz}, 1 \mathrm{H}, \mathrm{H}-4), 5.97$ (dm, J 15.7 Hz, 1H, H-6), 7.16 (dd, J 15.7, 6.9 Hz, 1H, H-7). ${ }^{13} \mathrm{C}$ NMR (75.4 MHz, $\left.\mathrm{CDCl}_{3}\right) \delta 18.2\left(\mathrm{CH}_{3} \mathrm{C}=\right), 25.4$ $\left(\mathrm{CH}_{3} \mathrm{CO}\right), 113.6(\mathrm{C}-4), 121.1(\mathrm{C}-6), 147.8$ (C-7), 151.5 (C3), $164.1(\mathrm{C}-5), 191.9\left(\mathrm{COCH}_{3}\right)$. IR (film) $v_{\max } / \mathrm{cm}^{-1}: 1777$, 1737, 1652, 1286, 1116, 1101, 973, 938. HRMS (FAB, $\left.\mathrm{MH}^{+}\right)(m \mathrm{NBA})$ : Found 155.0704; Calc. for $\mathrm{C}_{8} \mathrm{H}_{11} \mathrm{O}_{3}$ : 155.0708 .

$\left(1 R^{*}, 2 R^{*}, 4 R^{*}\right)-2-$ Acetylbicyclo[2.2.1]hept-5-en-2-yl 2methylacrylate (7a). (1R*,2S*,4R*)-2-Acetylbicyclo [2.2.1]hept-5-en-2-yl 2-methylacrylate (8a)

Method A. In a screw-capped ACE pressure tube, under $\mathrm{N}_{2}$ atmosphere, a mixture of $0.10 \mathrm{~g}(0.65 \mathrm{mmol})$ of $\mathbf{3 a}$, and $0.056 \mathrm{~g}(0.85 \mathrm{mmol})$ of 6 in dry $\mathrm{CH}_{2} \mathrm{Cl}_{2}(2 \mathrm{~mL})$ was stirred at room temperature for $3 \mathrm{~h}$. The solvent was removed under vacuum, and the residue was purified by column chromatography on silica gel (hexane/EtOAc, 100:2), giving $0.118 \mathrm{~g}(83 \%)$ of a mixture of $\mathbf{7 a} / \mathbf{8 a}(69: 31)$ as a greenish oil.
Method $B$. Under $\mathrm{N}_{2}$ atmosphere and at $-78^{\circ} \mathrm{C}$, a mixture of $0.10 \mathrm{~g}(0.65 \mathrm{mmol})$ of $\mathbf{3 a}, 0.173 \mathrm{~g}(1.3 \mathrm{mmol})$ of $\mathrm{AlCl}_{3}$, and $0.056 \mathrm{~g}(0.85 \mathrm{mmol})$ of 6 in dry $\mathrm{CH}_{2} \mathrm{Cl}_{2}(2 \mathrm{~mL})$ was stirred for $3 \mathrm{~h}$. The mixture was diluted with $\mathrm{CH}_{2} \mathrm{Cl}_{2}(50$ $\mathrm{mL}$ ), and washed with aqueous saturated solution of $\mathrm{NaHCO}_{3}(2 \times 30 \mathrm{~mL})$. The organic phase was dried $\left(\mathrm{Na}_{2} \mathrm{SO}_{4}\right)$, the solvent was removed under vacuum, and the residue was purified by column chromatography on silica gel (hexane/EtOAc, 9:1), giving $0.127 \mathrm{~g} \mathrm{(89 \% )} \mathrm{of} \mathrm{a} \mathrm{mixture}$ of $\mathbf{7 a} / \mathbf{8 a}(72: 28)$.

Method C. According to Method B, a mixture of 0.10 $(0.65 \mathrm{mmol})$ of $\mathbf{3 a}, 0.056(0.85 \mathrm{mmol})$ of $\mathbf{6}$, and $0.123 \mathrm{~g}$ $(0.65 \mathrm{mmol})$ of $\mathrm{TiCl}_{4}$ was allowed to react to give $0.088 \mathrm{~g}$ $(62 \%)$ of a mixture of $\mathbf{7 a} / \mathbf{8 a}(75: 25)$.

Method D. According to Method B, a mixture of 0.10 $(0.65 \mathrm{mmol})$ of $\mathbf{3 a}, 0.056(0.85 \mathrm{mmol})$ of $\mathbf{6}$, and $0.207 \mathrm{~g}$ $(0.65 \mathrm{mmol})$ of $\mathrm{ZnI}_{2}$ for $10 \mathrm{~h}$ was allowed to react to give $0.074 \mathrm{~g}(52 \%)$ of a mixture of 7a/8a (57:43).

Method E. According to Method B, a mixture of 0.10 $(0.65 \mathrm{mmol})$ of $\mathbf{3 a}, 0.056(0.85 \mathrm{mmol})$ of $\mathbf{6}$, and $0.092 \mathrm{~g}$ $(0.65 \mathrm{mmol})$ of $\mathrm{BF}_{3} . \mathrm{Et}_{2} \mathrm{O}$ was allowed to react to give 0.097 $\mathrm{g}(68 \%)$ of a mixture of $\mathbf{7 a} / \mathbf{8 a}(63: 37)$ as a greenish oil. The isomers were separated by radial chromatography (hexane/EtOAc, 100:2), giving $0.036 \mathrm{~g}$ (25\%) of 7a as a pale yellow oil and $0.026 \mathrm{~g}(18 \%)$ of $\mathbf{8 a}$ as a greenish oil.

Data of 7a. Rf 0.60 (hexane/EtOAc, 8:2). ${ }^{1} \mathrm{H}$ NMR (300 $\left.\mathrm{MHz} \mathrm{CDCl}_{3}\right) \delta 1.16$ (dd, J 12.9, 3.6 Hz, 1H, H-3n), 1.44 (dm, J 9.3 Hz, 1H, H-7s), 1.64 (br d, J $9.3 \mathrm{~Hz}, 1 \mathrm{H}, \mathrm{H}-7 \mathrm{a}$ ), 1.91 (br s, $3 \mathrm{H}, \mathrm{CH}_{3} \mathrm{C}=$ ), 2.16 (s, 3H, $\mathrm{CH}_{3} \mathrm{CO}$ ), 2.68 (dd, $J$ 12.9, $3.9 \mathrm{~Hz}, 1 \mathrm{H}, \mathrm{H}-3 \mathrm{x}$ ), 2.92 (br s, 1H, H-4), 3.15 (br s, $1 \mathrm{H}$, H-1), 5.60-5.63 (m, 1H, $\mathrm{CH}_{2}=$ ), 6.09 (br s, $1 \mathrm{H}, \mathrm{CH}_{2}=$ ), 6.12 (dd, J 5.4, 3.0 Hz, 1H, H-6), 6.41 (dd, J 5.4, 2.8 Hz, 1H, H5). ${ }^{13} \mathrm{C}$ NMR (75.4 MHz, $\left.\mathrm{CDCl}_{3}\right) \delta 18.1\left(\mathrm{CH}_{3} \mathrm{C}=\right), 24.5$ $\left(\mathrm{CH}_{3} \mathrm{CO}\right), 38.1$ (C-3), $42.1(\mathrm{C}-4), 46.5$ (C-7), 49.5 (C-1), $93.0(\mathrm{C}-2), 126.6\left(\mathrm{CH}_{2}=\right), 132.5(\mathrm{C}-6), 135.8\left(\mathrm{CH}_{3} \mathrm{C}=\right)$, $140.4(\mathrm{C}-5), 167.4\left(\mathrm{CO}_{2}\right), 205.7\left(\mathrm{CH}_{3} \mathrm{CO}\right)$. IR (film) $v_{\max }$ ' $\mathrm{cm}^{-1}: 1715,1634,1452,1434,1354,1334,1303,1242$, 1173, 1152, 1130, 1050, 949. MS (70 eV) m/z $221\left(\mathbf{M}^{+}+1\right.$, 21), $220\left(\mathrm{M}^{+}, 12\right), 177$ (9), 135 (53), 107 (76), 91 (15), 69 (100), 66 (50). HRMS (FAB, $\left.\mathrm{MH}^{+}\right)(\mathrm{mNBA})$ : Found 221.1182; Calc. for $\mathrm{C}_{13} \mathrm{H}_{17} \mathrm{O}_{3}: 221.1178$.

Data of 8a. Rf 0.47 (hexane/EtOAc, 8:2). ${ }^{1} \mathrm{H}$ NMR (300 $\left.\mathrm{MHz}, \mathrm{CDCl}_{3}\right) \delta 1.62$ (dd, J 12.9, 3.6 Hz, 1H, H-3x), 1.69 (dm, J $9.6 \mathrm{~Hz}, 1 \mathrm{H}, \mathrm{H}-7 \mathrm{~s}$ ), 1.93 (br d, $J 9.6 \mathrm{~Hz}, 1 \mathrm{H}, \mathrm{H}-7 \mathrm{a}$ ), 1.97 (br s, 3H, $\mathrm{CH}_{3} \mathrm{C}=$ ), 2.09 (s, 3H, $\left.\mathrm{CH}_{3} \mathrm{CO}\right), 2.35$ (dd, $J$ 12.9, 3.0 Hz, 1H, H-3n), 2.95 (br s, 1H, H-4), 3.07 (br s, 1H, $\mathrm{H}-1), 5.64-5.67$ (m, 1H, $\left.\mathrm{CH}_{2}=\right), 5.78(\mathrm{dd}, J 5.5,3.3 \mathrm{~Hz}, 1 \mathrm{H}$, H-6), 6.19 (br s, 1H, CH =), 6.37 (dd, J 5.5, 3.3 Hz, 1H, H5). $\left.{ }^{13} \mathrm{C} \mathrm{NMR} \mathrm{(75.4} \mathrm{MHz,} \mathrm{CDCl}_{3}\right) \delta 18.2\left(\mathrm{CH}_{3} \mathrm{C}=\right), 25.6$ $\left(\mathrm{CH}_{3} \mathrm{CO}\right), 37.2$ (C-3), 42.1 (C-4), 49.1 (C-7), 51.1 (C-1), $92.2(\mathrm{C}-2), 126.6\left(\mathrm{CH}_{2}=\right), 129.8(\mathrm{C}-6), 136.0\left(\mathrm{CH}_{3} \mathrm{C}=\right)$, 
141.7 (C-5), $167.3\left(\mathrm{CO}_{2}\right), 204.0\left(\mathrm{CH}_{3} \mathrm{CO}\right) . \mathrm{IR}$ (film) $v_{\max } / \mathrm{cm}^{-1}: 1722,1455,1332,1304,1243,1151,1046$. HRMS (FAB, $\left.\mathrm{MH}^{+}\right)(\mathrm{mNBA})$ : Found 221.1179 Calc. for $\mathrm{C}_{13} \mathrm{H}_{17} \mathrm{O}_{3}: 221.1178$.

(E)-But-2-enoic acid (1R*,2R*,4R*)-2-Acetylbicyclo [2.2.1]hept-5-en-2-yl ester (7b). (E)-But-2-enoic acid $\left(1 R^{*}, 2 S^{*}, 4 R^{*}\right)-2$-acetylbicyclo[2.2.1]hept-5-en-2-yl ester $(8 \boldsymbol{b})$

Method A. According to Method A for the preparation of $\mathbf{7 a} / \mathbf{8 a}$, a mixture of $0.10 \mathrm{~g}(0.65 \mathrm{mmol})$ of $\mathbf{3 b}$, and 0.056 $\mathrm{g}(0.85 \mathrm{mmol})$ of $\mathbf{6}$ was allowed to react to give $0.111 \mathrm{~g}$ $(78 \%)$ of a mixture of $\mathbf{7 b} / \mathbf{8 b}(59: 41)$ as a greenish oil.

Method B. According to Method B for the preparation of $\mathbf{7 a} / \mathbf{8 a}$, a mixture of $0.10(0.65 \mathrm{mmol})$ of $\mathbf{3 b}, 0.056(0.85$ $\mathrm{mmol})$ of 6 , and $0.086 \mathrm{~g}(0.65 \mathrm{mmol})$ of $\mathrm{AlCl}_{3}$ was allowed to react to give $0.087 \mathrm{~g}(61 \%)$ of a mixture of $\mathbf{7 b} / \mathbf{8 b}(68: 32)$.

Method C. According to Method C for the preparation of $\mathbf{7 a} / \mathbf{8 a}$, a mixture of $0.10(0.65 \mathrm{mmol})$ of $\mathbf{3 b}, 0.056(0.85$ $\mathrm{mmol})$ of $\mathbf{6}$, and $0.123 \mathrm{~g}(0.65 \mathrm{mmol})$ of $\mathrm{TiCl}_{4}$ was allowed to react to give $0.068 \mathrm{~g} \mathrm{(48 \% )}$ ) of a mixture of $\mathbf{7 b} / \mathbf{8 b}$ (54:46).

Method D. According to Method D for the preparation of 7a/8a, a mixture of $0.10(0.65 \mathrm{mmol})$ of $\mathbf{3 b}, 0.056(0.85$ $\mathrm{mmol})$ of $\mathbf{6}$, and $0.207 \mathrm{~g}(0.65 \mathrm{mmol})$ of $\mathrm{ZnI}_{2}$ was allowed to react to give $0.091 \mathrm{~g}(64 \%)$ of a mixture of $\mathbf{7 b} / \mathbf{8 b}(61: 39)$. The isomers were separated by radial chromatography (hexane/EtOAc, 100:2), giving $0.05 \mathrm{~g}$ (35\%) of $7 \mathbf{b}$ as a greenish oil and $0.03 \mathrm{~g}(21 \%)$ of $\mathbf{8 b}$ as a colorless oil.

Data of $7 \boldsymbol{b}$. $R f 0.57$ (hexane/EtOAc, 8:2). ${ }^{1} \mathrm{H}$ NMR (300 $\left.\mathrm{MHz} \mathrm{CDCl}_{3}\right) \delta 1.10$ (dd, J 12.9, $\left.3.9 \mathrm{~Hz}, 1 \mathrm{H}, \mathrm{H}-3 \mathrm{n}\right), 1.36$ (dm, J $9.1 \mathrm{~Hz}, 1 \mathrm{H}, \mathrm{H}-7 \mathrm{~s}$ ), 1.56 (br d, J $9.1 \mathrm{~Hz}, 1 \mathrm{H}, \mathrm{H}-7 \mathrm{a}$ ), 1.82 (dd, J6.9, $\left.1.8 \mathrm{~Hz}, 3 \mathrm{H}, \mathrm{CH}_{3} \mathrm{CH}=\right), 2.08$ (s, 3H, $\mathrm{CH}_{3} \mathrm{CO}$ ), 2.57 (dd, J 12.9, 3.9 Hz, 1H, H-3x), 2.83 (br s, 1H, H-4), 3.07 (br s, 1H, H-1), 5.75 (dq, J 15.4, $1.8 \mathrm{~Hz}, 1 \mathrm{H}, \mathrm{O}_{2} \mathrm{CCH}=$ ), 6.03 (dd, J 5.7, 3.3 Hz, 1H, H-6), 6.33 (dd, J 5.7, 2.8 Hz, 1H, $\mathrm{H}-5), 6.90$ (dq, $\left.J 15.4,6.9 \mathrm{~Hz}, 1 \mathrm{H}, \mathrm{CH}_{3} \mathrm{CH}=\right) .{ }^{13} \mathrm{C} \mathrm{NMR}$ $\left(75.4 \mathrm{MHz}, \mathrm{CDCl}_{3}\right) \delta 18.1\left(\mathrm{CH}_{3} \mathrm{C}=\right), 24.9\left(\mathrm{CH}_{3} \mathrm{CO}\right), 38.1$ (C-3), 42.0 (C-4), 46.6 (C-7), 49.3 (C-1), 92.5 (C-2), 122.0 $\left(\mathrm{O}_{2} \mathrm{CCH}=\right), 132.7(\mathrm{C}-6), 140.4(\mathrm{C}-5), 146.3\left(\mathrm{CH}_{3} \mathrm{C}=\right), 166.4$ $\left(\mathrm{CO}_{2}\right), 205.9\left(\mathrm{CH}_{3} \mathrm{CO}\right)$. IR (film) $v_{\max } / \mathrm{cm}^{-1}: 1718,1652$, 1442, 1354, 1334, 1318, 1289, 1272, 1191, 1160, 1053, 997, 968. MS (70 eV) m/z 220 (M+, 4), 193 (5), 177 (10), 155 (3), 134 (9), 69 (100), 66 (13). HRMS (FAB, MH ${ }^{+}$) ( $m$ NBA): Found 221.1178; Calc. for $\mathrm{C}_{13} \mathrm{H}_{17} \mathrm{O}_{3}: 221.1178$.

Data of $8 \boldsymbol{b}$. Rf 0.50 (hexane/EtOAc, 8:2). ${ }^{1} \mathrm{H}$ NMR (300 $\left.\mathrm{MHz}, \mathrm{CDCl}_{3}\right) \delta 1.53(\mathrm{dd}, J 13.2,3.7 \mathrm{~Hz}, 1 \mathrm{H}, \mathrm{H}-3 \mathrm{x}), 1.60$ (dm, J 8.7 Hz, 1H, H-7s), 1.82-1.87 (m, 1H, H-7a), 1,84 (dd, $\left.J 7.2,1.8 \mathrm{~Hz}, 3 \mathrm{H}, \mathrm{CH}_{3} \mathrm{CH}=\right), 2.00$ (s, 3H, $\mathrm{CH}_{3} \mathrm{CO}$ ), 2.26 (dd, $J$ 13.2, 3.0 Hz, 1H, H-3n), 2.86 (br s, 1H, H-4), 2.96 (br s, 1H, H-1), 5.68 (dd, J 5.4, 3.0 Hz, 1H, H-6), 5.86 (dq, J 15.6, 1.5 $\left.\mathrm{Hz}, 1 \mathrm{H}, \mathrm{O}_{2} \mathrm{CCH}=\right), 6.28$ (dd, J 5.4, $\left.2.8 \mathrm{~Hz}, 1 \mathrm{H}, \mathrm{H}-5\right), 6.98$ (dq,
$J$ 15.6, $\left.6.9 \mathrm{~Hz}, 1 \mathrm{H}, \mathrm{CH}_{3} \mathrm{CH}=\right) .{ }^{13} \mathrm{C} \mathrm{NMR}\left(75.4 \mathrm{MHz}, \mathrm{CDCl}_{3}\right)$ $\delta 18.1\left(\mathrm{CH}_{3} \mathrm{C}=\right), 25.5\left(\mathrm{CH}_{3} \mathrm{CO}\right), 37.2(\mathrm{C}-3), 42.1(\mathrm{C}-4), 49.1$ (C-7), $51.0(\mathrm{C}-1), 91.8(\mathrm{C}-2), 122.1\left(\mathrm{O}_{2} \mathrm{CCH}=\right), 129.7(\mathrm{C}-6)$, 141.5 (C-5), $146.3\left(\mathrm{CH}_{3} \mathrm{C}=\right), 166.3\left(\mathrm{CO}_{2}\right), 204.0\left(\mathrm{CH}_{3} \mathrm{CO}\right)$. IR (film) $v_{\max } / \mathrm{cm}^{-1}: 1720,1653,1442,1353,1333,1318$, $1288,1254,1189,1172,1151,1102,1046,1002,968 . \mathrm{MS}$ $(70 \mathrm{eV}) \mathrm{m} / \mathrm{z} 220$ (M+, 7), 177 (11), 155 (6), 134 (15), 69 (100), 66 (25). HRMS (FAB, $\left.\mathrm{MH}^{+}\right)(m \mathrm{NBA})$ : Found 221.1184; Calc. for $\mathrm{C}_{13} \mathrm{H}_{17} \mathrm{O}_{3}: 221.1178$.

\section{1-Furan-2-ylmethyl-2-oxopropyl 2-methylacrylate (11a)}

Under $\mathrm{N}_{2}$ atmosphere, a mixture of $0.2 \mathrm{~g}(1.3 \mathrm{mmol})$ of 3a and $1.0 \mathrm{~g}(14.7 \mathrm{mmol})$ of $\mathbf{9}$ in dry $\mathrm{CH}_{2} \mathrm{Cl}_{2}(6 \mathrm{~mL})$ was cooled down to $-78^{\circ} \mathrm{C}$, and $0.056 \mathrm{~g}(0.395 \mathrm{~mol})$ of $\mathrm{BF}_{3} . \mathrm{Et}_{2} \mathrm{O}$ were added dropwise. The mixture was stirred at room temperature for $12 \mathrm{~h}$, neutralized with an aqueous saturated solution of $\mathrm{NaHCO}_{3}(10 \mathrm{~mL})$, and extracted with $\mathrm{CH}_{2} \mathrm{Cl}_{2}$ $(2 \times 20 \mathrm{~mL})$. The organic extracts were dried $\left(\mathrm{MgSO}_{4}\right)$, the solvent was removed under vacuum, and the residue was purified by column chromatography on silica gel (hexane/ EtOAc, 95:5), giving $0.17 \mathrm{~g}(59 \%)$ of 11a as a greenish oil. $R f 0.70$ (hexane/EtOAc, 8:2). ${ }^{1} \mathrm{H} \mathrm{NMR}\left(300 \mathrm{MHz}, \mathrm{CDCl}_{3}\right.$ ) $\delta 1.95$ (br s, $3 \mathrm{H}, \mathrm{CH}_{3} \mathrm{C}=$ ), 2.13 (s, 3H, $\mathrm{CH}_{3} \mathrm{CO}$ ), 3.17-3.20 (m, 2H, furanyl- $\left.\mathrm{CH}_{2}\right), 5.31(\mathrm{t}, J 6.2 \mathrm{~Hz}, 1 \mathrm{H}, \mathrm{OCHCOMe})$, 5.63-5.67 (m, 1H, $\left.\mathrm{CH}_{2}=\right), 6.10$ (br d, J $3.2 \mathrm{~Hz}, 1 \mathrm{H}$, furanyl$\mathrm{H}_{3}$ ), 6.18 (br s, $1 \mathrm{H}, \mathrm{CH}_{2}=$ ), 6.29 (dd, J 3.0, $2.0 \mathrm{~Hz}, 1 \mathrm{H}$, furanyl- $\left.\mathrm{H}_{4}\right), 7.31-7.33\left(\mathrm{~m}, 1 \mathrm{H}\right.$, furanyl-H5). ${ }^{13} \mathrm{C} \mathrm{NMR}(75.4$ $\left.\mathrm{MHz}, \mathrm{CDCl}_{3}\right) \delta 18.2\left(\mathrm{CH}_{3} \mathrm{C}=\right), 26.6\left(\mathrm{CH}_{3} \mathrm{CO}\right), 29.6$ (furanyl$\mathrm{CH}_{2}$ ), 76.8 (OCHCOMe), 108.0 (furanyl-H), 110.5 (furanyl$\mathrm{H}), 126.9\left(\mathrm{CH}_{2}=\right), 135.3\left(\mathrm{CH}_{3} \mathrm{C}=\right), 142.1$ (furanyl- $\left.\mathrm{C}_{5}\right)$, 149.7 (furanyl- $\left.\mathrm{C}_{2}\right), 166.2\left(\mathrm{CO}_{2}\right), 205.2\left(\mathrm{CH}_{3} \mathrm{CO}\right)$. IR (film) $v_{\max } / \mathrm{cm}^{-1}: 1721,1452,1356,1298,1155,1078,1011$. HRMS (FAB, $\left.\mathrm{MH}^{+}\right)(\mathrm{mNBA})$ : Found 223.0966; Calc. for $\mathrm{C}_{12} \mathrm{H}_{15} \mathrm{O}_{4}: 223.0970$.

(E)-But-2-enoic acid 1-furan-2-ylmethyl-2-oxopropyl ester (11b)

According to the method used to prepare 11a, the reaction of $0.2 \mathrm{~g}(1.3 \mathrm{mmol})$ of $\mathbf{3 b}$ with $1.0 \mathrm{~g}(14.7 \mathrm{mmol})$ of $\mathbf{9}$ yielded $0.086 \mathrm{~g}(30 \%)$ of $\mathbf{1 1 b}$ as a greenish oil. $R f 0.80$ (hexane/EtOAc, 8:2). ${ }^{1} \mathrm{H} \mathrm{NMR}\left(300 \mathrm{MHz}, \mathrm{CDCl}_{3}\right) \delta 2.11$ (dd, J 7.2, $\left.1.8 \mathrm{~Hz}, 3 \mathrm{H}, \mathrm{CH}_{3} \mathrm{CH}=\right), 2.13$ (s, 3H, $\mathrm{CH}_{3} \mathrm{CO}$ ), 3.09-3.18 (m, 2H, furanyl- $\left.\mathrm{CH}_{2}\right), 5.32(\mathrm{t}, J 6.8 \mathrm{~Hz}, 1 \mathrm{H}$, OCHCOMe), 5.87 (dq, J 11.4, 1.8 Hz, 1H, O CCH=), 6.10$6.13\left(\mathrm{~m}, 1 \mathrm{H}\right.$, furanyl- $\left.\mathrm{H}_{3}\right), 6.29(\mathrm{dd}, J 3.3,1.9 \mathrm{~Hz}, 1 \mathrm{H}$, furanyl$\left.\mathrm{H}_{4}\right), 6.44$ (dq, J 11.4, 7.2 Hz, 1H, $\left.\mathrm{CH}_{3} \mathrm{CH}=\right)$, 7.27-7.33 (m, $1 \mathrm{H}$, furanyl- $\left.\mathrm{H}_{5}\right) .{ }^{13} \mathrm{C} \mathrm{NMR}\left(75.4 \mathrm{MHz}, \mathrm{CDCl}_{3}\right) \delta 15.6$ $\left(\mathrm{CH}_{3} \mathrm{CH}=\right), 26.7\left(\mathrm{CH}_{3} \mathrm{CO}\right), 29.4$ (furanyl- $\left.\mathrm{CH}_{2}\right), 76.2$ (OCHCOMe), 107.9 (furanyl-H), 110.4 (furanyl-H), 119.4 
$\left(\mathrm{O}_{2} \mathrm{CCH}=\right), 141.9$ (furanyl- $\left.\mathrm{C}_{5}\right), 147.2\left(\mathrm{CH}_{3} \mathrm{CH}=\right), 149.7$ (furanyl- $\left.\mathrm{C}_{2}\right), 165.5\left(\mathrm{CO}_{2}\right), 205.3\left(\mathrm{CH}_{3} \mathrm{CO}\right) . \mathrm{IR}$ (film) $v_{\max } / \mathrm{cm}^{-1}: 1721,1655,1358,1293,1264,1178,1104$, 1010, 969. HRMS (FAB, $\left.\mathrm{M}^{+}\right)(m \mathrm{NBA})$ : Found 222.0293; Calc. for $\mathrm{C}_{12} \mathrm{H}_{14} \mathrm{O}_{4}$ : 222.0299 .

2-Oxo-1-thiophen-2-ylmethylpropyl 2-methylacrylate (12a)

According to the method used to prepare 11a, the reaction of $0.2 \mathrm{~g}(1.3 \mathrm{mmol})$ of $\mathbf{3 a}$ with $1.0 \mathrm{~g}(11.9 \mathrm{mmol})$ of $\mathbf{1 0}$ yielded $0.1 \mathrm{~g}$ (34\%) of 12a as a greenish oil. $R f 0.75$ (hexane/EtOAc, 8:2). ${ }^{1} \mathrm{H} \mathrm{NMR}\left(300 \mathrm{MHz}, \mathrm{CDCl}_{3}\right.$ ) $\delta 1.99$ (br s, $3 \mathrm{H}, \mathrm{CH}_{3} \mathrm{C}=$ ), 2.10 (s, 3H, $\mathrm{CH}_{3} \mathrm{CO}$ ), 3.36 (d, J $6.1 \mathrm{~Hz}$, $2 \mathrm{H}$, thiophenyl- $\left.\mathrm{CH}_{2}\right), 5.25$ (t, J $\left.5.8 \mathrm{~Hz}, 1 \mathrm{H}, \mathrm{OCHCOMe}\right)$, 5.67-5.72 (m, 1H, $\left.\mathrm{CH}_{2}=\right)$, 6.25-6.28 (m, $\left.1 \mathrm{H}, \mathrm{CH}_{2}=\right)$, $6.86(\mathrm{br}$ $\mathrm{d}, J 3.4 \mathrm{~Hz}, 1 \mathrm{H}$, thiophenyl-H $), 6.93(\mathrm{dd}, J 5.1,3.4 \mathrm{~Hz}, 1 \mathrm{H}$, thiophenyl- $\left.\mathrm{H}_{4}\right), 7.17$ (dd, $J 5.1,1.2 \mathrm{~Hz}, 1 \mathrm{H}$, thiophenyl$\left.\mathrm{H}_{5}\right) .{ }^{13} \mathrm{C}$ NMR $\left(75.4 \mathrm{MHz}, \mathrm{CDCl}_{3}\right) \delta 18.5\left(\mathrm{CH}_{3} \mathrm{C}=\right), 26.8$ ( $\left.\mathrm{CH}_{3} \mathrm{CO}\right), 31.0$ (thiophenyl- $\left.\mathrm{CH}_{2}\right), 78.8$ (OCHCOMe), 124.8 (thiophenyl- $\mathrm{C}_{5}$ ), 126.7 (thiophenyl-H), 126.8 (thiophenyl$\mathrm{H}), 127.0\left(\mathrm{CH}_{2}=\right), 135.3\left(\mathrm{CH}_{3} \mathrm{C}=\right), 137.2$ (thiophenyl- $\left.\mathrm{C}_{2}\right)$, $166.5\left(\mathrm{CO}_{2}\right), 205.3\left(\mathrm{CH}_{3} \mathrm{CO}\right)$. IR (film) $v_{\max } / \mathrm{cm}^{-1}: 1719$, 1435, 1357, 1298, 1157, 947. HRMS (FAB, $\left.\mathrm{MH}^{+}\right)(m \mathrm{NBA})$ : Found 239.0748; Calc. for $\mathrm{C}_{12} \mathrm{H}_{15} \mathrm{SO}_{3}: 239.0748$.

(E)-But-2-enoic acid 2-oxo-1-thiophen-2-ylmethylpropyl ester $(12 b)$

According to the method used to prepare 11a, the reaction of $0.2 \mathrm{~g}(1.3 \mathrm{mmol})$ of $\mathbf{3 b}$ with $1.0 \mathrm{~g}$ (11.9 mmol) of $\mathbf{1 0}$ yielded $0.16 \mathrm{~g}(52 \%)$ of $\mathbf{1 2 b}$ as a greenish oil. $R f 0.70$ (hexane/EtOAc, 8:2). ${ }^{1} \mathrm{H}$ NMR (300 MHz, $\mathrm{CDCl}_{3}$ ) $\delta 1.92$ (dd, J 6.9, $1.7 \mathrm{~Hz}, 3 \mathrm{H}, \mathrm{CH}_{3} \mathrm{CH}=$ ), 2.09 (s, 3H, $\mathrm{CH}_{3} \mathrm{CO}$ ), 3.31-3.36 (m, 2H, thiophenyl- $\left.\mathrm{CH}_{2}\right), 5.25(\mathrm{dd}, J 6.8,5.1 \mathrm{~Hz}$, $1 \mathrm{H}, \mathrm{OCHCOMe}), 5.94\left(\mathrm{dd}, J 15.6,1.7 \mathrm{~Hz}, 1 \mathrm{H}, \mathrm{O}_{2} \mathrm{CCH}=\right)$, 6.84-6.88 (m, 1H, thiophenyl- $\left.\mathrm{H}_{3}\right), 6.92(\mathrm{dd}, J 5.1,3.4 \mathrm{~Hz}$, $1 \mathrm{H}$, thiophenyl- $\left.\mathrm{H}_{4}\right), 7.10$ (dq, $\left.J 15.6,6.9 \mathrm{~Hz}, 1 \mathrm{H}, \mathrm{CH}_{3} \mathrm{CH}=\right)$, 7.18 (dd, J 5.1, $1.2 \mathrm{~Hz}, 1 \mathrm{H}$, thiophenyl- $\left.\mathrm{H}_{5}\right) .{ }^{13} \mathrm{C} \mathrm{NMR}(75.4$ $\left.\mathrm{MHz}, \mathrm{CDCl}_{3}\right) \delta 18.1\left(\mathrm{CH}_{3} \mathrm{CH}=\right), 26.7\left(\mathrm{CH}_{3} \mathrm{CO}\right), 30.9$ (thiophenyl- $\left.\mathrm{CH}_{2}\right), 78.2$ (OCHCOMe), $121.6\left(\mathrm{O}_{2} \mathrm{CCH}=\right)$, 124.7 (thiophenyl- $\mathrm{C}_{5}$ ), 126.6 (thiophenyl-H), 126.7 (thiophenyl-H), 137.4 (thiophenyl- $\left.\mathrm{C}_{2}\right), 146.7\left(\mathrm{CH}_{3} \mathrm{CH}=\right.$ ), $165.5\left(\mathrm{CO}_{2}\right), 205.4\left(\mathrm{CH}_{3} \mathrm{CO}\right)$. IR (film) $v_{\max } / \mathrm{cm}^{-1}: 1720$, 1653, 1437, 1359, 1291, 1262, 1172, 1103, 1070. Anal. Calc. for $\mathrm{C}_{12} \mathrm{H}_{14} \mathrm{SO}_{3}: \mathrm{C}, 60.48 ; \mathrm{H}, 5.92 ; \mathrm{S}, 13.45$; Found: C, $60.35 ; \mathrm{H}, 5.72 ; \mathrm{S}, 13.21$.

\section{Theoretical Calculations}

The $a b$ initio HF/6-31G(d,p) and DFT B3LYP/6-
$311 \mathrm{G}(\mathrm{d}, \mathrm{p})$ calculations were carried out using GAUSSIAN94 ${ }^{16}$ (PC-Linux). Geometries were optimized at the HF/6-31G(d,p) level, and these were employed as starting point for optimizations at the B3LYP/6-311G(d,p) level. The coefficients of the frontier molecular orbitals were obtained from the HF/6-31G(d,p) optimized geometries, considering the stability results obtained at the higher level. The transition states and adducts were characterized by vibrational frequency analyses carried out at the optimized geometries. A single imaginary vibrational frequency was obtained for all TSs.

\section{Acknowledgments}

We thank Fernando Labarrios for his help in spectrometric measurements. J.T. gratefully acknowledges DEPI/IPN (Grant 200410) and CONACYT (Grants 1570P-E9507 and 32273-E) for financial support; and he thanks OAS (F54111), CONACYT (250099), and COFAA-IPN (9711220214) for support during a sabbatical leave in USA. H.A.J.-V. thanks CONACYT (Grant 3251P) for financial support. R.H. is grateful to CONACYT for a graduate scholarship (91187), and to PIFI-IPN and the Ludwig K. Hellweg Foundation for partial scholarships. H.A.J.-V. and J.T. are fellows of the EDI/IPN and COFAA/IPN programs.

\section{References}

1. Tamariz, J.; Vogel, P.; Helv. Chim. Acta 1981, 64, 188.

2. Reyes, A.; Aguilar, R.; Muñoz, A. H.; Zwick, J.-C.; Rubio, M.; Escobar, J.-L.; Soriano, M.; Toscano, R.; Tamariz, J.; J. Org. Chem. 1990, 55, 1024.

3. Herrera, R.; Nagarajan, A.; Morales, M. A.; Méndez, F.; Jiménez-Vázquez, H. A.; Zepeda, L. G.; Tamariz, J.; J. Org. Chem. 2001, 66, 1252.

4. Sustmann, R.; Tetrahedron Lett. 1971, 2721; Houk, K. N.; Sims, J.; Watts, C. R.; Luskus, L. J.; J. Am. Chem. Soc. 1973, 95, 7301.

5. Jiménez-Vázquez, H. A.; Ochoa, M. E.; Zepeda, G.; Modelli, A.; Jones, D.; Mendoza, J. A.; Tamariz, J.; J. Phys. Chem. A 1997, 101, 10082.

6. Herrera, R.; Jiménez-Vázquez, H. A.; Modelli, A.; Jones, D.; Söderberg, B. C.; Tamariz, J.; Eur. J. Org. Chem. 2001, 4657.

7. García de Alba, O.; Chanona, J.; Delgado, F.; Zepeda, G.; Labarrios, F.; Bates, R. W.; Bott, S.; Juaristi, E.; Tamariz, J.; Anal. Quim. Int. Ed. 1996, 92, 108.

8. Inokuchi, T.; Tanigawa, S.-i.; Torii, S.; J. Org. Chem. 1990, 55, 3958.

9. Aguilar, R.; M.Sc. Dissertation, Escuela Nacional de Ciencias Biológicas, IPN, México, 2000. 
10. Olah, G. A.; Krishnamurti, R.; Prakash, G. K. S. In Comprehensive Organic Synthesis; Trost, B. M.; Fleming, I., eds., Pergamon Press: Oxford, 1991, vol. 3, p. 293-339; Bunce, R. A.; Reeves, H. D.; Synth. Commun. 1989, 19, 1109; Yadav, J. S.; Abraham, S.; Reddy, B. V. S.; Sabitha, G.; Synthesis 2001, 2165; Jensen, K. B.; Thorhauge, J.; Hazell, R. G.; Jørgensen, K. A.; Angew. Chem., Int. Ed. 2001, 40, 160.

11. Fleming, I.; Frontier Orbitals and Organic Chemical Reactions, John Wiley \& Sons: Chichester, 1976, p. 47-65.

12. García, J. I.; Mayoral, J. A.; Salvatella L.; Acc. Chem. Res. 2000, 33, 658, and references included therein; Yamabe, S.; Minato, T.; J. Org. Chem. 2000, 65, 1830; García, J. I.; Martínez-Merino, V.; Mayoral, J. A.; Salvatella, L.; J. Am. Chem. Soc. 1998, 120, 2415.

13. Loncharich, R. J.; Brown, F. K.; Houk, K. N.; J. Org. Chem. 1989, 54, 1129.

14. Mellor, J. M.; Webb, C. F.; J. Chem. Soc., Perkin Trans. II 1974, 17; Houk, K. N.; Luskus, L. J.; J. Am. Chem. Soc. 1971, 93, 4606; Fox, M. A.; Cardona, R.; Kiwiet, N. J.; J. Org. Chem. 1987, 52, 1469; Boucher, J.-L.; Stella, L.; Tetrahedron 1988, 44, 3595 .
15. Kahn, S. D.; Hehre, W. J.; J. Am. Chem. Soc. 1987, 109, 663. 16. Frisch, M. J.; Trucks, G. W.; Schlegel, H. B.; Gill, P. M. W.; Johnson, B. G.; Robb, M. A.; Cheeseman, J. R.; Keith, T.; Petersson, G. A.; Montgomery, J. A.; Raghavachari, K.; AlLaham, M. A.; Zakrzewski, V. G.; Ortiz, J. V.; Foresman, J. B.; Cioslowski, J.; Stefanov, B. B.; Nanayakkara, A.; Challacombe, M.; Peng, C. Y.; Ayala, P. Y.; Chen, W.; Wong, M. W.; Andres, J. L.; Reploge, E. S.; Gomperts, R.; Martin, R. L.; Fox, D. J.; Binkley, J. S.; Defrees, D. J.; Baker, J.; Stewart, J. P.; HeadGordon, M.; Gonzalez, C.; Pople, J. A.; GAUSSIAN94, Gaussian, Inc.: Pittsburgh, PA, 1995.

17. Schmidt, M. W.; Baldridge, K. K.; Boatz, J. A.; Elbert, S. T.; Gordon, M. S.; Jensen, J. H.; Koseki, S.; Matsunaga, N.; Nguyen, K. A.; Su, S. J.; Windus, T. L.; Dupui, M.; Montgomery, J. A.; J. Comput. Chem. 1993, 14, 1347.

Received: November 4, 2004 Published on the web: April 12, 2005 